\title{
The use of Geographical Information Systems for Tourism Marketing purposes in Aveiro region (Portugal)
}

\author{
Helena Albuquerque ${ }^{\mathrm{a}, \mathrm{d}, \mathrm{e}, \square}$, Carlos Costa ${ }^{\mathrm{b}, \mathrm{d}}$, Filomena Martins $\mathrm{s}^{\mathrm{c}, \mathrm{d}}$ \\ ${ }^{\text {a }}$ University Portucalense Infante D. Henrique, Rua Dr. António Bernardino de Almeida, 541, 4200-072 Porto, Portugal \\ ${ }^{\mathrm{b}}$ Department of Economics, Management, Industrial Engineering and Tourism, University of Aveiro, Campus Universitário de Aveiro, $3810-193$ Aveiro, Portugal \\ ${ }^{\mathrm{c}}$ Department of Environment and Planning, University of Aveiro, Campus Universitário de Aveiro, 3810-193 Aveiro, Portugal \\ a Research Unit on Competitiveness, Governance and Public Policies (GOVCOPP), University of Aveiro, 3810-193 Aveiro, Portugal \\ ${ }^{\mathrm{e}}$ REMIT - Research on Economics, Management and Information Technologies, University Portucalense Infante D. Henrique, Rua Dr. António Bernardino de Almeida, \\ 541, 4200-072 Porto, Portugal
}

\section{A R T I C L E I N F O}

\section{Keywords:}

GIS

Tourism marketing

Database

Aveiro

Decision making

\begin{abstract}
A B S T R A C T
Geographical Information Systems are tools that allow a better decision making process, accessing politicians and managers in tourism development and providing integrated touristic information. Furthermore, these are powerful tools for the development of destination marketing strategies. Aveiro web-based Geographical Information System was developed, with the purpose of integrating tourism resources in a common platform. Aveiro region is an important coastal wetland of Portugal that presents unique features which allow the development of a sustainable tourism activity, based on natural and cultural characteristics. Despite the diversified resources, it is observed that the Aveiro region needs a strong improvement regarding tourism development and marketing strategies. In this paper, it will be presented the methodology used for the implementation of the first step of this GIS (inventory of resources and creation of the database) and the potential of this tool for the development of a sustainable tourism marketing strategy.
\end{abstract}

\section{Introduction}

Geographical Information Systems (GIS) are tools that present very useful functionalities that can be used in tourism management, providing an integrated approach analysis of spatial and non-spatial data. The development of tools capable of supporting tourism decision making process and enabling potential visitors to get an overview of the touristic resources diversity, products and services, are the main purposes for the implementation of GIS applied to tourism marketing (Lee, Choi, Yoo, \& Oh, 2013; Supak, Brothers, Bohnenstiehl, \& Devine, 2015; Supak, Devine, Brothers, Rozier Rich, \& Shen, 2014; Turk, Kitapci, \& Dortyol, 2014).

Aveiro region in Portugal has growing in terms of tourism demand in the last years, which implies the necessary development of tourism marketing strategies in order to improve the experience of tourists when visiting this area. This region comprises 11 municipalities that are connected by the Ria de Aveiro lagoon ecosystem, which is being recognized as the main tourist point of interest of this region. Considering its location and resources biophysical characteristics, it represents an excellent case study for the development of sustainable tourism marketing strategies, based on the profit of natural potential of this area
(Albuquerque, 2013). Several documents sated already the necessity of giving priority to the attraction, development and diversification of economic activities such as tourism, water sports and recreation, which genuinely depend on the maintenance or improvement of coastal and lagoon area environmental quality. The challenge is to show that it is possible to develop a sustainable tourism marketing strategy based on local natural and cultural resources, considering Ria de Aveiro as the linkage of touristic activities. Territorial, cultural and environmental singularities of this region could contribute to the development of quality and attractive tourism products.

In this paper, it will be analysed the web-based GIS of Aveiro region, concerning tourism marketing purposes. The main purpose of this study is to examine the potentiality of the web-based GIS of Aveiro region for the development of tourism marketing strategies, with two di $\square$ erent approaches: to support tourism decision making processes and to improve the experience of the tourists in this region. To accomplish this purpose, this paper is organized in five sections - introduction, literature review, case study, main finding and conclusion and further research. In this first section, it is presented the aim of the study and the main purposes that is pretended to achieve. The literature review is focused on the conceptual analysis of GIS and tourism marketing

Corresponding author at: University Portucalense Infante D. Henrique, Rua Dr. António Bernardino de Almeida, 541, 4200-072 Porto, Portugal.

E-mail addresses: helenaa@upt.pt (H. Albuquerque), ccosta@ua.pt (C. Costa), filomena@ua.pt (F. Martins). 
through the presentation of di $\square$ erent case studies found in the literature. The third section describes the Aveiro region study area and presents the aims, methodology and results of GIS database development and its implementation, showing the potential of this tool for this region. The fourth section describes the main findings of the analysis of the case study, having in account tourism marketing purposes. Finally, the last section presents some conclusions and recommendations for future researches.

\section{Literature review}

\subsection{GIS and tourism}

Geographical Information Systems (GIS) are important tools since they have the ability to represent, store, manage, analyse, update and visualize spatial and non-spatial data (Church, 2002; Stojanovic, Djordjevic-Kajan, \& Stojanovic, 2000) in an integrated platform. These spatial and non-spatial data can be described as "geographically-referenced information [that] includes spatial data (graphical) components which describe the location and attribute components which describe properties for location" (Ahmad et al., 2010, p. 187).

These are powerful tools, since they can combine a geographical analysis with an attribute analysis, providing a better interpretation of the data that can be used in di $\square$ erent research fields. Thus, as Goodchild (1989, p. 1) refers GIS "is clearly something more than a mapping system, because of the emphasis on analysis rather thandisplay".

Tourism sector is a spatial phenomenon that requires spatial data collection and processing (Boers \& Cottrell, 2007), namely to identify features relationships and to analyse those relationships in a spatial context. Therefore, Geographical Information Systems can be considered as important business tools for tourism. As Mcadam (1999, p. 79) mentions "since most tourism planning problems can be shown to have spatial or geographical characteristics and tend to be increasingly multi-dimensional and complex, it is likely that projects could be more accurately managed using the techniques and tools found in a GIS environment".

Considering this statement, Bahaire \& Elliott-White (1999, p. 161) presented the functional capabilities of GIS related to tourism sector, namely tourism resources inventories, identifying most suitable locations for development, measuring tourism impacts, visitor management and visitor flows, analysing relationships associated with resources use, and assessing potential impacts of tourism development.

Thus, GIS is a tool that can be used for a multitude of functions extremely important in tourism management and planning. Regarding Bahaire and Elliott-White (1999) research, it is possible to refer that GIS tools are seen as an added value both to the decision making processes, accessing politicians and managers in tourism development, and also by providing integrated and spatial touristic information, capable of assisting tourists in planning their visits.

Some authors tried to accomplish a state-of-the-art about GIS applications in tourism. Mcadam (1999) identified a set of papers emphasizing the use of GIS in issues related to tourism management in sensitive and cultural context and the use, in early stage, of tourism development destinations. Bahaire and Elliott-White (1999) referred the use of GIS tools in tourism related issues, such as environmental management, travel costs and tourism development modelling, based on scenarios analysis. Nevertheless, these authors referred also new applications namely in the design and monitor of sustainable tourism (Bahaire \& Elliott-White, 1999). In the same way, Chancellor and Cole (2008) also identified a set of applications related to sustainable tourism and the need to provide capacities for stakeholders to tourism decision making processes. Farsari and Prastacos (2004) presented a literature review referring the benefits of using GIS in tourism management and planning. They have carried out a review of di $\square$ erent GIS application, categorizing them in tourism resource inventories; location suitability; measuring and monitoring tourism impacts; visitor flows and management; relationship associated with resource use; and assessing potential impacts of tourism development.

However, these same authors referred that the use of this technology applied to tourism sector is still scarce (Albuquerque et al., 2016; Boers \& Cottrell, 2007; Chancellor \& Cole, 2008; Farsari \& Prastacos, 2004; Mcadam, 1999), which turns the analysis more di $\square$ cult.

\subsection{GIS and tourismmarketing}

According to the use of GIS in tourism marketing, it was observed di $\square$ erent approaches and findings through the literature review. Some studies are related to the conceptual analysis of GIS in tourism marketing (Bertazzon, Crouch, Draper, \& Waters, 1997; ElliottWhite \& Finn, 1997; Feng \& Morrison, 2002) and others are more related to case studies where GIS was used as a tool for tourism marketing analysis (Ayed, Bazazo, Hasoneh, \& Ayed, 2010; Beeco et al., 2013; Bertazzon et al., 1997; Chancellor \& Cole, 2008; Chang \& Caneday, 2011; Feng \& Morrison, 2002; Jovanović \& Njeguš, 2008; Miller, 2008; Supak et al., 2014). First, it will be presented the analysis of papers concerning tourism marketing and GIS conceptual analyses, followed by the analyses of some case studies.

Bertazzon et al. (1997) presented a study where they identified current use and future prospects of GIS applications in tourism mar-

keting. They analysed possible applications of GIS in tourism marketing, considering the market and the organizations. According to the market, they found that GIS applications are focused on "the spatial task of finding, analysing and mapping market characteristics". On the

other hand, considering organizations, those applications are "concerned with the spatial tasks of locating, designing, and planning tourism development" (Bertazzon et al., 1997, p. 40), which means the use of GIS for product and destinations development. In this paper, authors realized an analysis of a case study - 'Alberta Ski resorts hypertext document'. This is a GIS application to tourism marketing or-

ganizations, presenting "real time information on weather and road conditions within the resort region" and providing "information on shortest routes and tours of the region" (Bertazzon et al., 1997, p. 56).

Elliott-White and Finn (1997) discussed the role of GIS tools in the context of new developments of tourism marketing theory, having in account the concepts of lifestyle and relationship marketing. This is a conceptual paper, related to the evolution of the marketing concept and its application to tourism sector. They have emphasized that GIS tools could benefit "tourism providers but also the destination itself" (ElliottWhite \& Finn, 1997, p. 78).

Feng and Morrison (2002) presented also a literature review about GIS, GIS and marketing and GIS and tourism marketing. Having in account the 8Ps (product, price, place, promotion, package, programming, partnership and people) of marketing mix and the five-step tourism and hospitality marketing system model, known as PRICE (Feng \& Morrison, 2002), they have presented a discussion about the use of GIS in tourism marketing, in each task of the PRICE model (Table 1).

They also presented a case-study in Brown County, Indiana, USA, focused on the market analysis for destination marketing. They concluded that GIS tools have strong potentialities for destination

Table 1

Tourism and hospitality marketing system tasks and steps: the PRICE model. Source: Feng \& Morrison, 2002, p. 133

\begin{tabular}{lll}
\hline Task/function & & Steps/questions \\
\hline Planning and research & $\mathrm{P}$ & Where are we now? \\
& $\mathrm{R}$ & Where would we like to be? \\
Implementation & $\mathrm{I}$ & How do we get there? \\
Control evaluation & $\mathrm{C}$ & How do we make sure we get there? \\
& $\mathrm{E}$ & How do we know if we get there? \\
\hline
\end{tabular}




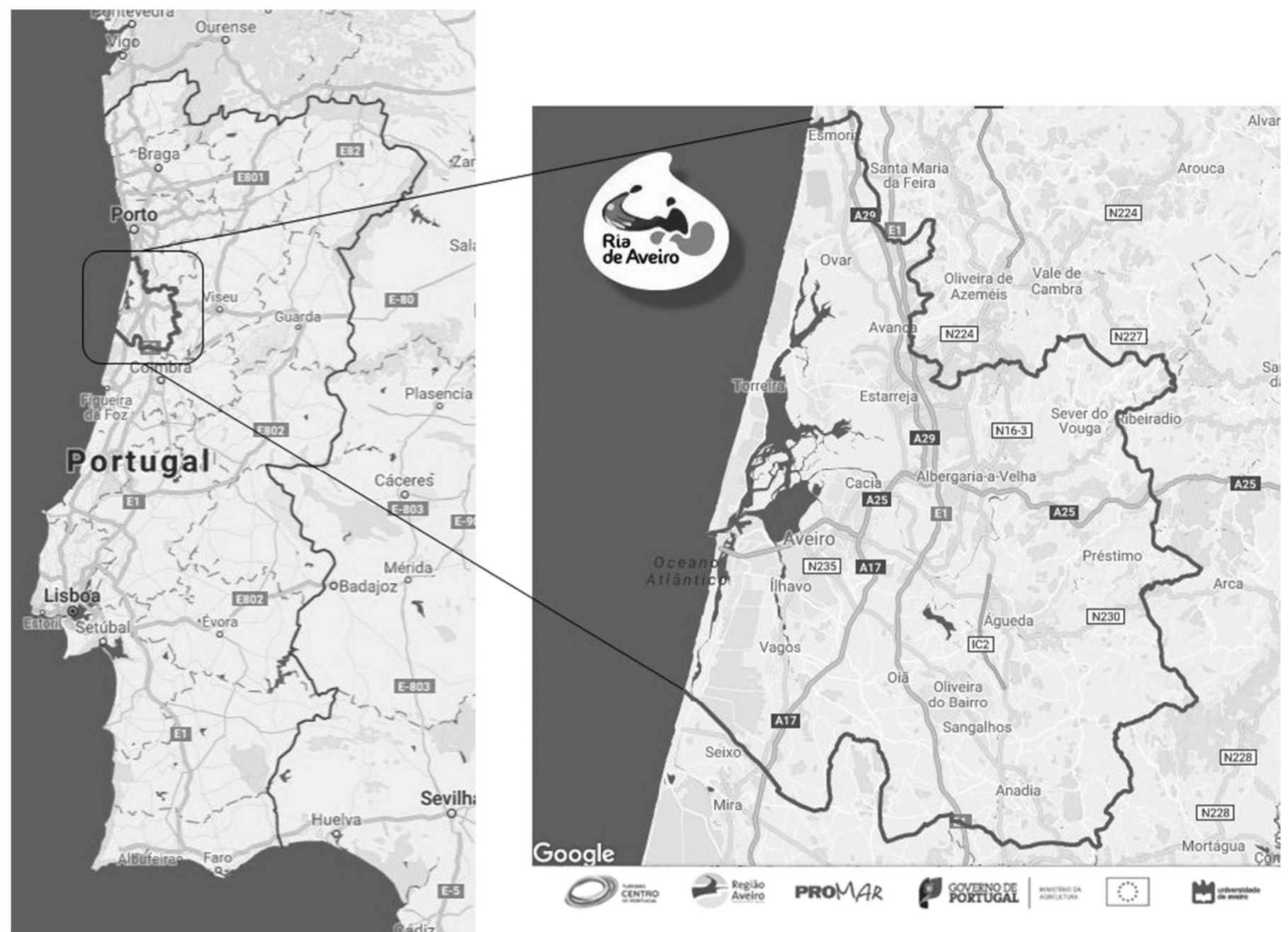

Fig. 1. Aveiro region.

Source: http://sig.riadeaveiro.pt/web/.

marketing, namely in what concerns product planning, information communications and promotion; and also to support decision making processes. Nevertheless, they refer that those are not a "panacea for all problems and challenges" (Feng \& Morrison, 2002, p. 140), which means a need of having a strong awareness and understating about GIS applications. They also refer that GIS tools should be used with other techniques and technologies, in order to improve its performance.

Concerning the analyses of case studies, it was noticed that most of them are related to destination marketing organizations. However, some papers analyse both market desires and necessities and marketing organizations, emphasizing the importance of GIS in this field.

Chancellor \& Cole (2008, p. 348) presented a study with the purpose of "apply GIS to travel pattern data in an e $\square$ ort to further illuminate the attraction linkages from the tourists' perspectives, which would high- light potential collaboration partners for Jackson County tourism pro- moters" and "to explore tourists' trip origins through the use of their home zip code data, in an e $\square$ ort to determine potential new or expanded markets for the destination". They found that this GIS application brings benefits to destination stakeholders and that could be used in the decision making process.

Jovanović and Njeguš (2008) analysed the use of GIS in three types of applications: inventory, analysis and evaluation of plan based on tourism development. Their purpose was to create a GIS with the collected tourist data in such a way that these data could be analysed, modelled and presented in an integrated manner. This would allow, according to the authors, a better development, management and marketing of Zlatibor and Zlatar tourist destination.

Miller (2008) presented an analysis of a hypothetical retailer, with the purpose to understand the importance of GIS tools in market analysis for tourism-dependent retailers, to design marketing strategies. This author concluded that GIS tools "allow the tourism-dependent retailer to improve service to existing customers and make highly focused, attractive o $\square$ ers to new prospects" (Miller, 2008, p. 339) being in this way a very useful tool for tourism marketing strategies.

Ayed et al. (2010) discussed the importance of creating tourism marketing database in Petra, Jordan, using GIS. The main issues of this study were: "to develop a geographic database, including all tourist sites in Petra city; to promote tourist sites in Petra city especially in light of Petra being voted as one of the New Seven Wonders of the World.; to identify the actual role of GIS applications in tourism marketing in the context of the continual growth of tourism sector" (Ayed et al., 2010, p. 145). Despite this study being related to the implementation of a decision support tool for tourism planning and marketing, the authors also concluded that GIS can "perform several tasks in the marketing of tourist sites. Performance starts from supply and demand to market segmentation to identifying the characteristics of tourists to end up with e $\square$ ective promotion of tourist sites." (Ayed et al., 2010, p. 151).

Chang and Caneday (2011) also realized a study about destination marketing. These authors argue that a "WebGIS o $\square$ ers an integrated platform that has the ability to satisfy people's information needs by o $\square$ ering rich information. The highly-visualized natural and interactive 
functionality of WebGIS may bring some powerful tools to tourism marketing" (Chang \& Caneday, 2011, p. 1437), namely by providing them for the decision support processes. Besides that, these same authors have discussed tourist perceptions about the use and interaction with web GIS platform in di $\square$ erent travel situations and tasks.

Supak et al. (2014, p. 835) presented a study where they have developed a "decision support tool for tourism planning and marketing that is customized and easy to use, employs open source software to reduce expense, and allows for broad accessibility via web delivery". This study can also be seen from the two perspectives of tourism marketing, since it can be seen as an added value to market analysis through the customer profiling (market) and also it can be seen as decision support tool (organizations), helping marketers in defining their market area.

\section{Case study: Aveiro region, Portugal}

\subsection{Aveiro region characterization and main aims}

Aveiro region is characterised by the presence of a lagoon (Ria de Aveiro) that occupies more than 11,000 ha, with almost $45 \mathrm{~km}$ of length and $8,5 \mathrm{~km}$ width (Fidélis, 2001). This lagoon is under the territory of 10 municipalities Águeda, Albergaria-a-Velha, Anadia, Aveiro, Estarreja, Ílhavo, Murtosa, Oliveira do Bairro, Ovar and Vagos, that, together with Sever do Vouga comprise the study area (Fig. 1). This area is one of the most, more expressive and biologically more significant coastal wetland of Portugal (D'Abreu, Correia, \& Oliveira, 2004), constituting a unique landscape with diverse potential resources: port platform, fishing zone, production of artisanal salt, aquaculture, agriculture, development of nautical sports, tourism and nature protection.

It is an area that presents diversified natural and cultural resources, such as maritime and fluvial beaches, river fronts, forests, natural reserves, mountain villages, architectonic and archeologic patrimony, and museums, between others. The proximity between lowland coasts and mountains creates conditions for the existence of diversified landscapes, namely valleys, mountain landscapes, contrasting with the lowland sand beaches and a huge lagoon area that shapes the territory, being, therefore, considered as a great environmental and heritage quality area. These characteristics should be used for sustainable tourism development and for the design of marketing strategies.

In order to understand the potential and challenge of GIS to tourism marketing, it was carried out an analysis to a web GIS applied to tourism in Aveiro region (http://sig.riadeaveiro.pt/web/), developed under the PRORia project (Tourism Brand Project - axis 4 of PROMAR Programme 2007-2013 - Fisheries Operational Programme).

The main objectives of this web GIS development were (Albuquerque et al., 2016, p. 73):

- "The identification, data collection and analysis of touristic resources, products and services available in the region;

- The creation of a common and share database, which include all information collected about the tourism resources, products and services available in the region;

- The creation of a Geographical Information System, capable of aiding promotional actions and sustainable management of tourism activity in the region, and also capable of serving as a tool to support decision making process;

- The creation of a web-based Geographical Information System, making available to tourists a suitable tool to support their trips planning."

From the literature review, it is possible to place this GIS in the main issues of tourism marketing, since it was developed in order to support tourism marketing organizations and tourism market desires and necessities (Bertazzon et al., 1997), through the provision of a common platform of tourism resources.

\subsection{Aveiro Web-based GIS implementation}

The methodology used for the development of this web-bases GIS was divided in data collecting, through the analysis of documentary information and meetings with the Central Portugal Regional Tourism Board (TCP); development of the database schema, with ArcGIS diagrammer, according to the Central Portugal Regional Tourism Board (TCP) products; analysis of information in the existing databases; field work; and data entry in the database, using ArcGIS software.

The first step for the implementation of the Aveiro tourism GIS was to realize a survey to know the existing available data concerning tourism resources and products. This was an important process since the objective was to organize and to create a common and updated database of this area. In this way, it was identified sources information, which has conducted to the recognition of several ones. The main sources consulted were: POLIS Ria de Aveiro, Aveiro Digital, SecurRia, BioRia, NaturRia projects; Nature 2000 Sectorial Plan; Strategic Tourism Plan of Rota da Luz; Unir@Ria Plan (Strategic Intermunicipal Plan of Aveiro Region); national and regional tourism entities databases; and regional and municipal entities databases. It was also used the o $\square$ cial national cartography produced and Open Street map GIS database. In this analysis we found that several sources had information in di $\square$ erent formats, since excel and word sheets for attribute data; and DGN, Shape and Geodatabase formats, for geographical data. As outcome of this survey, it was compiled data tables, in order to evaluate which database fields exist in each source of information and how to integrate it in a common database.

The second step was to aggregate databases taking into account the strategic products defined by TCP, namely Cultural and Landscape Touring; Nature; Nautical; Gastronomy \& Wine, Sun \& Sea, Business and Golf products. To do this aggregation, these compiled tables were presented to TCP and CIRA (Aveiro Region Intermunicipal Community) and discussed with them the fields (attribute data) that should exist for each product. ArcGIS diagrammer software was used in order to promote a better visualization of attributes data of each product. The final product of this step was database and schema development for tourism products of the Aveiro region.

After the definition of database schema, it was analysed the information of the di $\square$ erent databases, in order to understand what information was missing. In the end, we found that a lot of information was missing and thus, it was necessary to programme field work to collect the missing data.

Finally, using ArcGIS software, the database was filled out, with the collected data from the di $\square$ erent databases analysed and from the field work. This has conducted to the development and creation of an integrated information geodatabase. This database was then delivered to TCP and CIRA to validate information.

\section{Results}

The development of this project led to the achievement of several results. First, it was developed an integrated and georeferenced database of tourism resources and product of Ria de Aveiro region. This was one of the main tasks that Central Portugal Regional Tourism Board (TCP) wanted to develop, in order to have an inventory of region tourism resources, in a common platform and with a similar structure between di $\square$ erent products.

It was also desired by TCP to design some specific tourist routes for this region. Through the development of this integrated geodatabase, it was possible to define and to georeferenced those routes, namely Architecture route, Birdwatching route and Fishing route. Nevertheless, it should be possible to design more routes for the region, namely by combining di $\square$ erent types of products and resources (multi-attraction or multi-typology routes). 


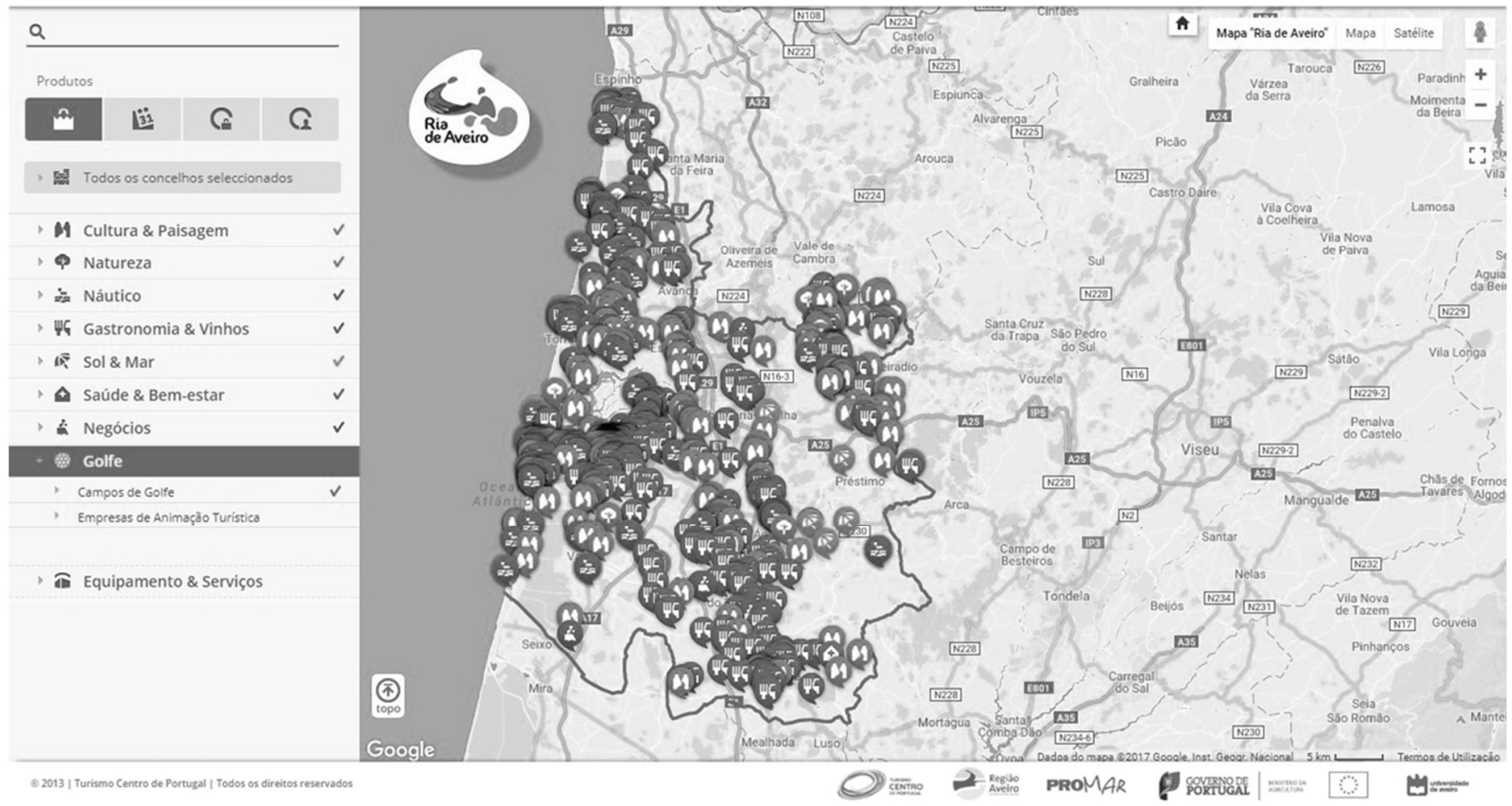

Fig. 2. Aveiro web-based GIS

Source: http://sig.riadeaveiro.pt/web/.

A third result was the launching of a web-based GIS platform (http://sig.riadeaveiro.pt/web/) as a tool that supports both the decision making processes and tourists that plans to visit de destination (Fig. 2).

Another output of the project was the availability of a tool that can promote the region in an easier way. Having an integrated platform of all tourism products and resources allowed the development of di $\square$ erent marketing strategies realized by the TCP. At the same time, a destina- tion brand was also created and associated to this web-GIS platform.

\subsection{Further development}

It was considered, as already referred, that this inventory was the first step of the implementation of the Aveiro region GIS. The created geodatabase was delivered to the Central Portugal Regional Tourism Board (TCP) and it was released online. Nevertheless, further developments are needed, in order to analyse its impact in the tourism marketing and in tourism planning and development of the destination. It is considered necessary the geodatabase monitoring, in order to have always the platform updated. This is important, since this is an online platform (web-based GIS) and the information should be always

updated in order to not mislead tourist that want to visit the destination.

The development of this geodatabase will also be able to support decision makers as Ayed et al. (2010); Bahaire and Elliott-White (1999); Chang and Caneday (2011); Feng and Morrison (2002); Supak et al. (2014) have referred in their analysis. It is thought that this GIS tool can support the implementation of a sustainable tourism marketing strategy for this region, through the integrated analysis of all tourism products and resources and through the integration of di $\square$ erent stakeholders that are able to use this tool. Nevertheless, to achieve this task, it is considered essential to realize an assessment of the web-GIS platform use, in order to understand how it is being used, both by tourism providers (stakeholders and decision makers) and consumers (tourists). Thus, it 
would be important to conduct a research to achieve two main objectives: to identify and to determine the users of the online platform, both tourism providers and consumers; and to develop a sustainable tourism strategy of the destination, having in account the most demand tourism resources and products of the destination.

\section{Main findings}

From the literature review it was possible to verify that GIS tools are important for the development of tourism marketing, both having in account market and organizations. Nevertheless, it was revealed that the main research about GIS and tourism marketing is related to the management of destinations (organizations), since these are powerful tools that allow an integrated analysis of attributes and geographical data, which is an added-value for the decision making processes and for the development of marketing strategies (Ayed et al., 2010; Bertazzon et al., 1997; Elliott-White \& Finn, 1997; Feng \& Morrison, 2002; Jovanović \& Njeguš, 2008; Supak et al., 2014; Supak et al., 2015). However, some studies related to market were also found in the lit- erature (Bertazzon et al., 1997; Chancellor \& Cole, 2008; Chang \& Caneday, 2011; Feng \& Morrison, 2002; Miller, 2008). In these studies it was highlighted the importance of GIS tools, namely for the definition of market areas and costumers, and for considering tourist behaviours and perceptions, which could also help decision-makers (namely private ones) to define their marketing strategies in attracting clients.

Considering Ria de Aveiro tourism GIS, this is placed in the first task/function of PRICE model: planning and research (Morrison, 2002, cited in Feng \& Morrison, 2002), since this geodatabase can be con- sidered as an inventory of the touristic resources that exist in this destination. Nevertheless, the release of this geodatabase in a web-GIS platform is believed to perform the task "implementation" of the same model, through the possibility that tourists and decision makers could have in knowing resources and products of the Aveiro region 
destination. As Feng and Morrison (2002) refer, this GIS platform will allow a better product planning, information and promotion of the destination.

At the moment, this GIS is able to realize di $\square$ erent functional capabilities (Bahaire \& Elliott-White, 1999), namely data entry, storage and manipulation; map production; data queries; searches and spatial analysis. Thus, this GIS can be used by TCP in order to realize destination marketing.

Despite GIS tools potential in tourism marketing, some limitations were also identified. First, it should be mentioned that GIS tools are still used in a limited manner by tourism sector, and consequently by tourism marketing (Ayed et al., 2010; Bertazzon et al., 1997; Chen, 2007; Elliott-White \& Finn, 1997; Feng \& Morrison, 2002; Jovanović \& Njeguš, 2008; Miller, 2008; Supak et al., 2014; Supak et al., 2015). This limited use brings some research gaps, namely the scarce assumptions about the real importance of these tools in tourism marketing. Although literature review has strengthened that importance, it is still need more research to prove that outcome.

Secondly, the most common limitation identified was the complexity (Elliott-White \& Finn, 1997; Supak et al., 2014) and cost of GIS tools (Ayed et al., 2010; Bertazzon et al., 1997; Feng \& Morrison, 2002; Miller, 2008; Supak et al., 2014). GIS tools require some level of knowledge to the use of these technologies (Feng \& Morrison, 2002), which means a necessity of interdisciplinary studies development or even the training of tourism actors (tourist, tourism industry, physical planning authorities, etc.) on these technologies use. Also, GIS tools, namely proprietary GIS (Bertazzon et al., 1997; Supak et al., 2014) are very expensive, which is a problem to small entrepreneurs. Nevertheless, this could be an opportunity, since stakeholders could develop partnerships in order to benefit from these tools, through the sharing of the same platform.

Concerning Aveiro tourism GIS, these same limitations were also identified. There is still a scarce use of GIS tools by tourism sector, namely by TCP and these tools are considered very complex and very expensive. Nevertheless, some other limitations were also found, namely related to the design of database schema. As it was referred before, tourist information was spread through $\mathrm{di} \square$ erent databases and in di $\square$ erent formats. This information was also incomplete which have led to development of more field work than was expected. Finally, some of those databases were not directly realized for tourism sector, leading to the necessity of creating specific tourism fields for the attributes that this GIS database should compiled.

\section{Conclusions and further research}

Since the nineties, GIS applications into tourism sector and tourism marketing have evolved, due to the perception that these are powerful tools for tourism development and planning. The increasing use of digital and online technologies opens the spectrum of opportunities to develop new applications for tourism marketing, which would benefit destinations and visitors. However, it is notorious the lack of research in these fields, which open the range of options for further researches.

Through the development of this analysis, it was possible to recognize two research fields: the opportunity for web GIS platforms development and the need of more research related to tourist behaviours and perceptions.

It seems interesting to develop an analysis of web GIS platforms, from the point of view of the stakeholders. Besides the fact that literature review considered important these tools for decision making processes, it should be interesting to know what stakeholders think: are they really important for tourism marketing? How are these stakeholders using them? How do they promote these platforms? Which benefits the existence of online platforms have brought for destinations and/or tourism industry? What kind of practice should tourism actors have to use GIS tools, in order to benefit from these tools? Is there a big di $\square$ erence between proprietary and Open-source software?
Literature review also pointed out the gap of GIS application in tourist behaviours and perceptions research. Therefore, it should also be interesting to analyse these platforms from the point of view of visitors: is it important for visitors to have knowledge about the destinations prior to the visit? How do these platforms help in the travel planning? Will these platforms change the behaviour of tourist in the destination?

\section{References}

Ahmad, S. Z., Syed Abdullah, S. L., Rosmani, A. F., Hashim, N. M., Lutfi, N. A., Halim, N., \& Halim, H. A. (2010). Integrating GIS technology and 3D animation in an event information system. CSSR 2010-2010 international conference on science and social research (pp. 187-190). . http://dx.doi.org/10.1109/CSSR.2010.5773763.

Albuquerque, H. (2013). Estratégia de Desenvolvimento Sustentável do Turismo na Ria de Aveiro. Universidade de Aveiro [sustainable tourism development strategy in Ria de Aveiro]. Universidade de Aveiro.

Albuquerque, H., Martins, F., Raposo, R., Cardoso, L. G., Beça Pereira, P., \& Dias, P. (2016). Construction of a web-based geographical information system - The case of "Ria de Aveiro" region. Anatolia, 27(1), 71-81. http://dx.doi.org/10.1080/ 13032917.2015.1083210.

Ayed, M., Bazazo, I., Hasoneh, A., \& Ayed, B. (2010). Using geographic information system to visualize travel patterns and market potentials of Petra City in Jordan. International Journal of Marketing Studies, 2(2), 144-159. http://dx.doi.org/10.5539/ ijms.v2n2p144.

Bahaire, T., \& Elliott-White, M. (1999). The application of Geographical Information Systems (GIS) in sustainable tourism planning: A review. Journal of Sustainable Tourism, 7(2), 159-174. http://dx.doi.org/10.1080/09669589908667333.

Beeco, J. A., Huang, W.-J., Hallo, J. C., Norman, W. C., McGehee, N. G., McGee, J., \& Goetcheus, C. (2013). GPS tracking of travel routes of wanderers and planners. Tourism Geographies, 15(3), 551-573. http://dx.doi.org/10.1080/14616688.2012. 726267.

Bertazzon, S., Crouch, G., Draper, D., \& Waters, N. (1997). GIS applications in tourism marketing: Current uses, an experimental application and future prospects. Journal of Travel \& Tourism Marketing, 6(3-4), 35-59. http://dx.doi.org/10.1300/ J073v06n03_04.

Boers, B., \& Cottrell, S. (2007). Sustainable tourism infrastructure planning: A GIS-supported approach. Tourism Geographies: AnInternationalJournalofTourismSpace, Place and Environment, 9(1), 1-21. http://dx.doi.org/10.1080/14616680601092824.

Chancellor, C., \& Cole, S. (2008). Using geographic information system to visualize travel patterns and market research data. Journal of Travel \& Tourism Marketing, 25(3-4), 341-354. http://dx.doi.org/10.1080/10548400802508440.

Chang, G., \& Caneday, L. (2011). Web-based GIS in tourism information search: Perceptions, tasks, and trip attributes. Tourism Management, 32(6), 1435-1437. http://dx.doi.org/10.1016/j.tourman.2011.01.006.

Chen, R. J. C. (2007). Geographic information systems (GIS) applications in retail tourism and teaching curriculum. Journal of Retailing and Consumer Services, 14(4), 289-295. http://dx.doi.org/10.1016/j.jretconser.2006.07.004.

Church, R. L. (2002). Geographical information systems and location science. Computers \& Operations Research, 29(6), 541-562. http://dx.doi.org/10.1016/S0305 0548(99)00104-5.

D'Abreu, A. C., Correia, T. P., \& Oliveira, R. (2004). In A. C. D'Abreu, T. P. Correia, \& R. Oliveira (Vol. Eds.), Contributos para a Identificação e Caracterização da Paisagem em Portugal Continental. [Contribution to the landscape identification and characterization in Portugal]. Vol. 3. Lisboa: Direcção Geral do Ordenamento do Território e Desenvolvimento Urbano.

Elliott-White, M. P., \& Finn, M. (1997). Growing in sophistication: The application of Geographical Information Systems in post-modern tourism marketing. Journal of Travel \& Tourism Marketing, 7(1), 65-84. http://dx.doi.org/10.1300/J073v07n01_05.

Farsari, Y., Prastacos, P., Lew, A. A., Hall, C. M., \& Williams (2004). GIS Applicatios in the planning and management of tourism. A companion to tourism (pp. 596-607). (1 st ed.). Blackweel Publishing. http://dx.doi.org/10.1002/9780470752272.ch47.

Feng, R., \& Morrison, A. M. (2002). GIS applications in tourism and hospitality marketing: A case in Brown County, Indiana. Anatolia, 13(2), 127-143. http://dx.doi.org/10. 1080/13032917.2002.9687129.

Fidélis, T. (2001). Planeamento territorial e ambiente: o caso da envolvente à Ria de Aveiro. [Territorial planning and environment: The case of Ria de Aveiro surrounding]. Cascais: Principia.

Goodchild, M. (1989). Geographic information systems and market research. Papers and Proceedings of Applied Geography Conferences 12 (pp. 1-8).

Jovanović, V., \& Njeguš, A. (2008). The application of gis and its components in tourism. Yugoslav Journal of Operations Research, 18(2), 261-272. http://dx.doi.org/10.2298/ YUJOR0802261J.

Lee, S.-H., Choi, J.-Y., Yoo, S.-H., \& Oh, Y.-G. (2013). Evaluating spatial centrality for integrated tourism management in rural areas using GIS and network analysis. Tourism Management, 34, 14-24. http://dx.doi.org/10.1016/j.tourman.2012.03.005.

Mcadam, D. (1999). The value and scope of Geographical Information Systems in Tourism Management.Journalof Sustainable Tourism, 7(1), 77-92.http://dx.doi.org/10.1080/ 09669589908667327.

Miller, F. L. (2008). Using a Gis in market analysis for a tourism-dependent retailer in the Pocono Mountains. Journal of Travel \& Tourism Marketing, 25(3-4), 325-340. http:// dx.doi.org/10.1080/10548400802508416.

Stojanovic, Z., Djordjevic-Kajan, S., \& Stojanovic, D. (2000). Visual query and analysis 
tool of the object-relational GIS framework. Proceedings of the ninth international conference on information and knowledge management - CIKM 'OO (pp. 328-335). New York, New York, USA: ACM Press. http://dx.doi.org/10.1145/354756.354836.

Supak, S., Brothers, G., Bohnenstiehl, D., \& Devine, H. (2015). Geospatial analytics for federally managed tourism destinations and their demand markets. Journal of Destination Marketing and Management, 4(3), 173-186. http://dx.doi.org/10.1016/j. jdmm.2015.05.002.

Supak, S. K., Devine, H. A., Brothers, G. L., Rozier Rich, S., \& Shen, W. (2014). An open source web-mapping system for tourism planning and marketing. Journal of Travel \& Tourism Marketing, 31(7), 835-853. http://dx.doi.org/10.1080/10548408. 2014.890153.

Turk, T., Kitapci, O., \& Dortyol, I. T. (2014). The usage of Geographical Information Systems (GIS) in the marketing decision making process: A case study for determining supermarket locations. Procedia - Social and Behavioral Sciences, 148, 227-235. http://dx.doi.org/10.1016/j.sbspro.2014.07.038.

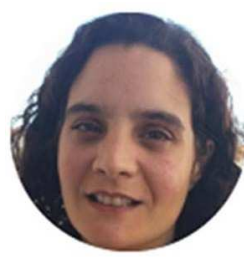

Helena Albuquerque holds a $\mathrm{PhD}$ in Environmental Sciences and Engineering, MSc in Coastal Zones Sciences and a BSc in Geography. She also holds an advanced training course (long-term) in Tourism. At the moment, she is Assistant Professor in University Portucalense Infante D. Henrique (Porto - Portugal). She has published articles in scientific national and international journals and she has also participated in di $\square$ erent research projects developed in the University of Aveiro. Her main interest areas of research are Sustainable Tourism, Tourism and Environment, Integrated Coastal Zones Management, Geographic Information Systems applied to tourism and Wellness Tourism. She is member of the research Unit on Competitiveness, Governance and Public Policies

(GOVCOPP) of the University of Aveiro and of the Research on Economics, management and Information Technologies (REMIT) of the University Portucalense Infante D. Henrique.

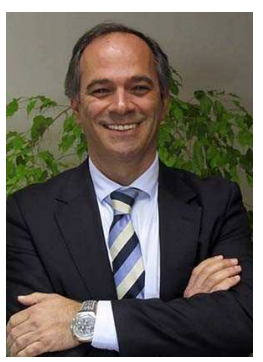

Carlos Costa is Full Professor (Professor Catedrático), Head of the Department of Economics, Management and Industrial Engineering of the University of Aveiro, Editor of the Journal of Tourism \& Development (Revista de Turismo e Desenvolvimento) and President of the Agency for Assessment and Accreditation of Higher Education (A3ES), for the university tourism courses. He holds a $\mathrm{PhD}$ and $\mathrm{MSc}$ on Tourism Management (University of Surrey, UK), and a BSc on Urban and Regional Planning (University of Aveiro, Portugal). Carlos is the leader of the $\mathrm{PhD}$ Tourism Programme of the University of Aveiro and is also the head of the Tourism Research Centre of the University of Aveiro (include in GOVCOPP and evaluated by the Portuguese Government with 'Excellent'). $\mathrm{He}$ is also Scientific Coordinator of the "idtour-unique solutions" - tourism spin-o $\square$ company (private sector) located in the University, responsible for the transference of knowledge and innovation to the tourism sector. Carlos is involved in a number of national and international tourism projects.

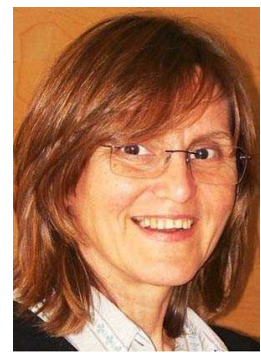

Filomena Martins is Associated Professor at Environmen and Planning Department of Aveiro University, where she teaches diverse courses and supervise diverse master and $\mathrm{PhD}$ students. She is also collaborator of Centre for Environmental and Marine Studies (CESAM) associated laboratory. Her principal research areas are Integrated Marine and Coastal Zone Management, Soil Use Changes, Citizenship and Participation, Conservation of Natural and Cultural Heritage, Environmental Education and Training, Risk Policies and Social Perception, Environmental Impact Assessment Studies, Sustainable Development and Loca Agenda 21. She has coordinated and participated in different national and international scientific projects in these fields. Currently has been involved in, "DESIRE -

Desertification, Mitigation and Remediation of Land" (FP6/SustDev/IP 037046), (participation - 2007-2012); "IBERMAR - Red IberoAmericana de Manejo Costero Integrado", (408RT0335), Programa Iberoamericano de Ciencia y Tecnología para el Desarrollo (CYTED-2007-2012); "ECOSALATLANTIS-Ecotourism in Atlantic traditional saltpans: a strategy to sustainable and integrated development", INTERREG IVB «Atlantic Area», (coordination of UA team - 2010-2013); "LTER-RAVE - Long term monitoring in the Ria de Aveiro: towards a deeper understanding of ecological, environmental and economic processes" (LTER/BIA-BEC/0063/2009), (participation -2011-2014); "APSAT - Action Publique, technologies Satellitaires et développement durable", INTERREG IVC Sudoeste SOE2/P1/F297(participant - 2011-2013); "AQUA_ADD - Deploying the added value of water in local and regional development”, INTERREG IVC - (consultant) 